\title{
ANALISIS POTENSI DAERAH UNTUK MENGEMBANGKAN WILAYAH DI KOTA TELUK KUANTAN KABUPATEN KUANTAN SINGINGI MENGGUNAKAN TEORI PUSAT PERTUMBUHAN
}

\author{
Haris Susanto, Meli Sasmi, A. Haitami \\ Universitas Islam Kuantan Singingi \\ susanto.haris79@yahoo.com, melisasmi2011@gmail.com
}

\begin{abstract}
Ringkasan
Penelitian ini bertujuan untuk mengkaji daerah/kecamatan mana yang berpotensi kuat dalam pertumbuhannya di wilayah se Kuantan Singingi dan mengetahui potensi apa yang dimiliki oleh masing-masing daerah/kecamatan di wilayah Kuantan Singingi. Penelitian ini dilaksanakan selama 4 bulan mulai dari bulan Juni sampai September 2017. Penelitian ini dilakukan dengan metode analisis data sekunder. Data yang digunakan adalah data sekunder dengan periode pengamatan tahun 2014 - 2016. Data yang diperlukan adalah data PDRB (berdasarkan harga konstan), PDRB per kapita, jumlah penduduk, dan jarak antar wilayah. Analisis data yang digunakan dalam penelitian ini yaitu analisis gravitasi dan model interaksi ruang dan analisis Location Quotient (LQ). Hasil dari analisis Klassen Typologi dengan pendekatan sektoral, menunjukkan bahwa sektor pertanian tanaman perkebunan khusunya karet dan kelapa sawit menduduki kuadran II yaitu sektor maju tapi tertekan. Selain itu, sektor ekonomi di Kabupaten Kuantan Singingi belum ada yang berada di kuadran I yaitu maju dan tumbuh cepat tapi masih banyak berada pada kuadran IV yaitu sektor yang relatif tertinggal. Hasil perhitungan nilai LQ diseluruh sektor pertanian khususnya tanaman perkebunan perekonomian yaitu tanaman karet di Kecamatan Kuantan Hilir Seberang $(1,77)$ dan Kecamatan Gunung Toar $(1,76)$ serta Kecamatan Singingi $(1,66)$ serta tanaman kelapa sawit juga cukup potensial di Kabupaten Kuantan Singingi karena memiliki nilai LQ lebih dari satu (LQ > 1, khususnya di Kecamatan Kuantan Mudik, Pucuk Rantau, Singingi Hilir dan Benai. Hal ini menunjukkan bahwa sektor-sektor tersebut memiliki kontribusi yang besar dalam perekonomian dan pembangunan wilayah di Kabupaten Kuantan Singingi
\end{abstract}

Key word : Potensi, pertumbuhan, pengembangan wilayah 


\section{PENDAHULUAN}

\subsection{Latar Belakang Masalah}

Penekanan pembangunan pada sektor modern perkotaan telah terbukti meningkatkan pertumbuhan di sektor dan lokasi yang hanya memiliki tingkat produktifitas tinggi. Laju pertumbuhan investasi dan akumulasi modal hanya terpusat di sektor modern tersebut. Konsep tersebut menginspirasikan terbentuknya pusat-pusat pertumbuhan di perkotaan. Diharapkan dengan terbentuknya pusat-pusat pertumbuhan tersebut akan terjadi proses penetesan pembangunan ke daerah-daerah belakang dan pemerataan akan terjadi secara "otomatis" dari kutubkutub pertumbuhan ke daerah belakang tersebut. Namun pada kenyataannya penetesan pembangunan itu tidak terjadi, dan yang terjadi adalah pengurasan sumberdaya yang dimiliki daerah oleh pusat secara besar-besaran. Paradigma pembangunan yang urban biased tersebut telah menimbulkan berbagai persoalan seperti terjadinya urbanisasi yang berlebihan (over urbanization) karena akumulasi kapital yang berada di perkotaan. Urbanisasi yang berlebihan tersebut pada akhimya menimbulkan berbagai persoalan di kota dan yang terjadi bukan lagi economies of scale (economies of agglomeration) namun justru diseconomies of scale. Kotakota besar tumbuh dengan cepat sebagai pusat pertumbuhan wilayah yang sering mengabaikan fungsinya untuk memberikan pelayanan kepada daerah terbelakang.

Untuk dapat tumbuh secara cepat, suatu negara perlu memilih satu atau lebih pusat-pusat pertumbuhan regional yang memiliki potensi paling kuat. Apabila region ini kuat maka akan terjadi perembetan pertumbuhan bagi region-region lemah. Pertumbuhan ini berdampak positif (trickle down effect) yaitu adanya pertumbuhan di region yang kuat akan menyerap potensi tenaga kerja di region yang lemah atau mungkin region yang lemah menghasilkan produk yang sifatnya komplementer dengan produk region yang kuat.

Mengembangkan wilayah di

Kota Teluk Kuantan Kabupaten Kuantan Singingi dengan menekankan pusat pertumbuhan wilayah utama dengan maksud agar pertumbuhan tersebut dapat menimbulkan dampak pertumbuhan bagi daerah-daerah di sekitarnya. Disamping itu dapat pula dikaji hubungan timbal balik antara Kota Teluk Kuantan Kabupaten Kuantan Singingi dengan daerah-daerah di sekitarnya. Diharapkan pertumbuhan yang pesat di Kota Teluk Kuantan Kabupaten Kuantan Singingi dapat menetes ke bawah (trickle down effect) dan menyebar ke daerahdaerah sekitarnya.

Pengembangan wilayah di Kota Teluk Kuantan Kabupaten Kuantan Singingi dengan pendekatan pusat pertumbuhan tepat digunakan untuk mengurangi ketimpanganketimpangan pertumbuhan antara wilayah karena sumberdaya yang tidak merata di masing-masing daerah. Untuk dapat tumbuh secara cepat maka wilayah Kota Teluk Kuantan Kabupaten Kuantan Singingi perlu menentukan hubungan pusat-daerah yang memiliki potensi yang paling kuat sehingga 
diharapkan dapat memicu pertumbuhan di daerah-daerah lain yang lemah. Untuk itu perlu dianalisis wilayah mana di Kabupaten Kuantan Singingi yang berpotensi kuat dalam pengembangannya dan potensi apa yang memungkinkan untuk dikembangkan dalam rangka meningkatkan pertumbuhan ekonomi daerah tersebut.

Dimana pertumbuhan kawasan andalan diharapkan dapat memberikan impas positif bagi pertumbuhan ekonomi daerah sekitar atau daerah dibelakangnya (hinterland), melalui pembudayaan sektor atau subsektor basis sebagai penggerak perekonomian daerah dan keterkaitan ekonomi antar daerah.

Dalam konteks pembangunan spasial, terjadi urban bias yang cenderung mendahulukan pertumbuhan ekonomi melalui kutub-kutub pertumbuhan yang diharapkan dapat menimbulkan efek penetesan (trickle down effect) ke wilayah hinterland-nya. Ternyata net-effect-nya menimbulkan pengurasan besar (massive backwash effect). Dengan perkataan lain, dalam konteks ekonomi telah terjadi transfer sumberdaya dari wilayah perdesaan ke kawasan perkotaan secara besar-besaran. Walaupun kawasan perkotaan juga berperan penting dalam mensuplai barangbarang dan pelayanan untuk pertumbuhan dan produktifitas pertanian.

Melihat kondisi yang demikian, masyarakat perdesaan secara rasional mulai melakukan migrasi ke wilayah perkotaan, yang semakin lama semakin deras (speed up proccesses), meskipun tidak ada jaminan bahwa mereka akan mendapatkan pekerjaan, tetapi bagi mereka kehidupan di kota lebih memberikan harapan untuk menambah penghasilan. Keadaan ini selanjutnya menimbulkan persoalanpersoalan terhadap masyarakat kawasan perkotaan, antara lain timbulnya pemukiman kumuh dan rumah liar, masalah kemacetan, keadaan sanitasi dan air bersih yang buruk, menurunnya kesehatan masyarakat dan pada gilirannya akan menurunkan produktifitas masyarakat di kawasan perkotaan.

Kota Teluk Kuantan

Kabupaten Kuantan Singingi yang merupakan obyek penelitian ini berdasarkan letaknya memiliki lokasi yang strategis. Kota Teluk Kuantan Kabupaten Kuantan Singingi terletak pada jalur transportasi regional utama Riau dan Sumatera Barat dan Kabupaten Indragiri Hulu yaitu antara Kota Pekanbaru dan Kota Rengat serta jalur lintas barat ke Sumatera Barat, dimana daerah tersebut telah berkembang, terutama Kota Pekanbaru dan Sumatera Barat yang menjadi kawasan andalan bagi daerah sekitarnya. Kondisi ini memungkinkan Kabupaten Kuantan Singingi memiliki keuntungan sebagai berikut;

- Kota Teluk Kuantan Kabupaten Kuantan Singingi akan berperan sebagai kota transit bagi para pelaku perjalanan antara Pekanbaru dan Rengat serta Sumbar. Dengan demikian akan mendorong perkembangan sektor perdagangan dan jasa terutama dalam distribusi produk dan potensi lokal.

- Kota Teluk Kuantan Kabupaten Kuantan Singingi berperan 
sebagai terminal (pusat) perdagangan hasil pertanian bagi daerah sekitarnya, penyedia alatalat dan input bagi kegiatan pertanian, serta sebagai pusat industri pengolahan pertanian. Peran ini didukung oleh keberadaan wilayah sekitar yang sangat potensial bagi pengembangan pertanian, baik tanaman pangan, buah, sayuran, dan hasil kebun lainnya.

- Selain itu Kabupaten Kuantan Singingi berimpit pada kawasan pusat pengembangan di Provinsi Riau, kebijakan pada wilayahwilayah tersebut akan membuka peluang besar bagi Kuanta Singingi untuk lebih berkembang. Terutama bagi sektor -sektor pertanian, perdagangan dan jasa, industri dan pariwisata.

$\begin{array}{ccr}\text { Hasil } & \text { pertanian } & \text { Kabupaten } \\ \text { Kuantan } & \text { Singingi } & \text { tujuan }\end{array}$ pemasarannya juga paling dominan adalah wilayah Pekanbaru. Namun disisi lain penyebaran kawasan industri di Kuantan Singingi tidak merata, sehingga perkembangan antar wilayah kurang cepat. Sedangkan perdagangan dan jasa juga tidak menyebar, yang menyebabkan sektor perdagangan kurang berkembang. Di sisi lain Kuantan Singingi yang memiliki lahan pertanian yang cukup luas, pemanfaatannya kurang maksimal.

Sehubungan dengan hal ini perlu dipelajari bagaimana sebenarnya potensi daerah dalam prospeknya untuk pengembangan suatu wilayah. Dengan demikian penulis tertarik untuk melakukan kajian dengan judul "Analisis Potensi Daerah Untuk Mengembangkan
Wilayah Di Kota Teluk Kuantan Kabupaten Kuantan Singingi Menggunakan Teori Pusat Pertumbuhan"

\subsection{Perumusan Masalah}

Berdasarkan latar belakang masalah di atas terlihat bahwa Kota Teluk Kuantan Kabupaten Kuantan Singingi yang memiliki letak yang strategis yaitu berada pada jalur lintas timur dana lintas barat, selain itu juga dekat dengan pusat perdagangan dan pusat pemerintahan Provinsi Riau yang berada di Kota Pekanbaru, adalah merupakan suatu keunggulan bagi Kota Teluk Kuantan Kabupaten Kuantan Singingi guna lebih mampu memanfaatkan letak yang strategis guna mendorong pembangunan ekonominya. Namun disisi lain pembangunan ekonomi Kota Teluk Kuantan Kabupaten Kuantan Singingi masih tersendat oleh beberapa masalah, diantaranya adalah penyebaran kawasan industri di Kota Teluk Kuantan Kabupaten Kuantan Singingi tidak merata, sehingga perkembangan antar wilayah kurang cepat. Sedangkan perdagangan dan jasa juga tidak menyebar, yang menyebabkan sektor perdagangan kurang berkembang.

Di sisi lain Kabupaten Kuantan Singingi yang memiliki lahan pertanian yang cukup luas, pemanfaatannya kurang maksimal. Keadaan ini merupakan masalah yang penting bagi Kuantan Singingi.

Pemerataan pembangunan wilayah perlu memperhatikan masalah potensi yang ada di wilayah tersebut mengingat potensi sumberdaya yang ada di masingmasing daerah tidak sama. Oleh karena itu agar perkembangan 
wilayah Kabupaten Kuantan Singingi dapat tumbuh secara cepat maka 1) perlu dikaji daerah/kecamatan mana yang berpotensi kuat dalam pertumbuhannya di wilayah se Kuantan Singingi dan 2) potensi apa yang dimiliki oleh masing-masing daerah/kecamatan di wilayah Kuantan Singingi ?

\subsection{Tujuan Penelitian}

Dengan memperhatikan permasalahan dan latar belakang, kemudian dirumuskan beberapa tujuan seperti di bawah ini :

1. Untuk mengkaji daerah/kecamatan mana yang berpotensi kuat dalam pertumbuhannya di wilayah se Kuantan Singingi.

2. Untuk mengetahui potensi apa yang dimiliki oleh masing-masing daerah/kecamatan di wilayah Kuantan Singingi.

\subsection{Manfaat Penelitian}

Manfaat dari penelitian ini adalah:

1. Bagi Pengembangan Ilmu Pengetahuan. Penelitian ini diharapkan dapat memberikan tambahan informasi bagi prospek dan peranan potensi daerah untuk mengembangkan wilayah menggunakan teori pusat pertumbuhan.

\subsection{Ruang Lingkup Kajian}

Dalam penelitian ini yang menjadi kajian adalah mengenai pendapatan asli daerah disetiap kecamatan, namun dalam penelitian ini yang menjadi pusat kajian adalah pendapatan yang bersumber dari sektor pertanian saja dan tidak memasukan pendapatan dari sektor non pertanian.

\section{METODE PENELITIAN}

\subsection{Metode dan Waktu Penelitian}

Penelitian ini dilakukan dengan metode analisis data sekunder. Penelitian ini mengambil obyek penelitian daerah-daerah tingkat kecamatan se Kuantan Singingi untuk menentukan interaksi yang paling kuat antar pusat kota Kota Teluk Kuantan Kabupaten Kuantan Singingi) dengan daerah-daerah sekitarnya. Penelitian ini dilakukan selama 4 bulan yang dimulai dari bulan Juni sampai bulan September 2017.

\subsection{Pengumpulan dan Sumber Data}

Data yang digunakan adalah data sekunder dengan periode pengamatan tahun 2014 - 2016. Data yang diperlukan adalah data PDRB (berdasarkan harga konstan), PDRB per kapita, jumlah penduduk, dan jarak antar wilayah. Data tersebut selanjutnya dianalisis dengan melakukan pendekatan deskriptif kuantitatif. Pendekatan deskriptif yaitu penyajian dan penyusunan data ke dalam tabel-tabel untuk dianalisis, sedangkan pendekatan kuantitatif adalah data yang diperoleh dianalisis dengan menggunakan model Location Quotient (LQ)

\subsection{Konsep Operasional}

1. Potensi Ekonomi merupakan kemampuan ekonomi yang dimiliki daerah yang mungkin atau layak dikembangkan sehingga akan terus berkembang menjadi 
sumber penghidupan rakyat setempat bahkan dapat menolong perekonomian daerah secara keseluruhan untuk berkembang dengan sendirinya dan berkesinambungan.

2. Produk Domestik Regional Bruto (PDRB) merupakan indikator untuk mengetahui kondisi perekonomian suatu wilayah, yang dapat dilihat berdasarkan harga berlaku atau atas dasar harga konstan. PDRB dimaksudkan sebagai jumlah nilai tambah yang dihasilkan oleh seluruh unit usaha yang ada dalam suatu wilayah dalam kurun waktu tertentu biasanya satu tahun.

3. Pertumbuhan Ekonomi merupakan pertumbuhan yang dimaksudkan adalah pertumbuhan PDRB rata-rata sejak tahun 2014-2016.

4. Pendapatan Perkapita merupakan perkiraan pendapatan perorangan yang dihasilkan dari PDRB pertahun dibagi dengan jumlah penduduk pada pertengahan tahun atau dengan kata lain pendapatan perkapita merupakan hasil bagi pendapatan regional dengan jumlah penduduk pertengahan tahun.

5. Sektor basis adalah sektor yang menjadi tulang punggung perekonomian daerah karena mempunyai keuntungan kompetitif (Competitive Advantage) yang cukup tinggi. Sedangkan sektor non basis adalah sektor-sektor lainnya yang kurang potensial tetapi berfungsi sebagai penunjang sektor basis atau service industries.

6. Location Quotient (LQ), yaitu suatu perbandingan tentang besarnya peranan suatu sektor/industri di suatu daerah terhadap besarnya peranan sektor/industri tersebut secara nasional

\subsection{Analisis Data}

Analisis data yang digunakan adalah: 1. Analisis gravitasi dan model interaksi ruang.

Analisis ini digunakan untuk mencari wilayah mana di Kuantan Singingi yang berpotensi kuat dalam pertumbuhannya. Adanya interaksi antara desa-kota menunjukkan eratnya hubungan antara wilayah 1 dengan wilayah 2 sebagai konsekuensi interaksi kota-desa dalam teori pusat pertumbuhan.

Adapun rumus untuk menghitung interaksi dalam hubungan desakota adalah (Suwarjoko, 1994)

$$
\mathrm{I}_{1,2}=\mathrm{a}\left(\mathrm{W}_{1} \mathrm{P}_{1}\right)\left(\mathrm{W}_{2} \mathrm{P}_{2}\right) / \mathrm{J}^{\mathrm{b}}{ }_{12}
$$

Keterangan :

I1,2 : Interaksi dalam wilayah 1 dan 2

W1 : Pendapatan perkapita wilayah 1

W2 : Pendapatan perkapita wilayah 2

P1 : Jumlah penduduk wilayah 1

P2 : Jumlah penduduk wilayah 2

J1,2 : Jarak antara wilayah 1 dan

2 (dalam meter)

a : konstanta yang nilainya 1

$\mathrm{b}$ : konstanta yang nilainya 2 .

2. Analisis Location Quotient (LQ) 
Pendekatan LQ merupakan suatu teknik analisis yang dimaksudkan untuk menentukan potensi spesialisasi suatu daerah terhadap aktifitas ekonomi utama atau untuk menentukan sektor unggulan yaitu sektor yang dapat memenuhi kebutuhan daerah sendiri dan daerah lain. Model yang digunakan dalam penelitian ini adalah model analisis Kadariah (1979). Dengan persamaannya sebagai berikut:

$$
\mathrm{LQ}=\mathrm{vi} / \mathrm{vt}: \mathrm{Vi} / \mathrm{Vt}
$$

Keterangan :

vi $=$ Pendapatan sektor tertentu pada suatu daerah.

$\mathrm{vt}=$ Total pendapatan daerah tersebut.

$\mathrm{Vi}=$ pendapatan sektor sejenis secara regional atau nasional

$\mathrm{Vt}=$ total pendapatan regional atau nasional.

Berdasarkan formulasi di atas maka apabila

a. LQ >1 berarti daerah mempunyai basis pada sektor tersebut dan ada kelebihan hasil yang dapat dipasarkan ke daerah lain.

b. $\mathrm{LQ}=1$ berarti hasil sektor tersebut hanya cukup untuk memenuhi kebutuhan daerah yang bersangkutan.

c. LQ $<1$ berarti daerah tidak mempunyai basis pada sektor tersebut dan ada kekekurangan hasil yang dibeli dari daerah lain

\section{BAB III. HASIL DAN PEMBAHASAN}

\subsection{Perekonomian Kabupaten Kuantan Singingi}

Struktur perekonomian suatu daerah sangat ditentukan oleh besarnya peranan sektor-sektor ekonomi dalam menciptakan nilai tambah. Makin besar nilai tambah yang diraih oleh suatu sektor maka semakin besar peranan dalam perekonomian daerah tersebut. Berdasarkan distribusi persentase PDRB atas harga berlaku menurut lapangan usaha, maka sektor pertanian merupakan sektor yang paling dominan memberikan kontribusi kepada PDRB Kuantan Singingi.

Besarnya kontribusi masingmasing sektor terhadap pertumbuhan PDRB Kabupaten Kuantan Singingi dapat dilihat pada Tabel 1 peranan terbesar dalam penciptaan nilai tambah yang diberikan oleh sektor pertanian, yakni sebesar 49,61 pada tahun 2016, walaupun sedikit mengalami peningkatan sebesar 0,13 persen dari tahun 2015. Untuk mempertahankan nilai pendapatan, pemerintah daerah kabupaten berupaya membuat kebijakan yang memberikan perhatian kepada sektor-sektor yang memberikan kontribusi kepada peningkatan perekonomian daerah.

$\begin{array}{ccc}\text { Kontribusi } & \text { kedua } & \text { terbanyak } \\ \text { adalah dari } & \text { sektor industri }\end{array}$ pengolahan, dengan arah peranan yang terus meningkat dari 1,50 persen menjadi 27,45 persen pada tahun 2016, dan mengalami penurunan sebesar 24,27 persen pada tahun 2015. Begitu juga sektor pertambangan dan penggalian yang 
menduduki peringkat ketiga menunjukkan tingkat pertumbuhan selalu menurun dari tahun ke tahun yaitu dari 9,54 persen pada tahun 2014 menurun menjadi 5,63 persen pada tahun 2015 dan 5,05 persen pada tahun 2016. Kemudian diikuti oleh sektor konstruksi yang selalu meningkat dari tahun ketahun dari

Tabel 1. Distribusi Persentase PDRB Kabupaten Kuantan Singingi Tahun 20142016 (dalam persen)

\begin{tabular}{|c|c|c|c|c|}
\hline $\mathrm{No}$ & $I_{a r}$ & 2014 & 2015 & 2016 \\
\hline 1 & Pertanian & 47,74 & 49.48 & 49.61 \\
\hline 2 & $\begin{array}{ll}\text { Pertambangan } & \text { dan } \\
\text { penggalian } & \end{array}$ & 9,54 & 5,63 & 5,05 \\
\hline 3 & Industri pengolahan & 25,77 & 1,50 & 27,45 \\
\hline 4 & Listrik dan gas & 0,02 & 0,03 & 0,04 \\
\hline 5 & $\begin{array}{l}\text { Pengadaan air, } \\
\text { pengelolaan sampah, } \\
\text { limpah dan daur ulang }\end{array}$ & 0,02 & 0,02 & 0,02 \\
\hline 6 & Konstruksi & 7,21 & 7,66 & 7,68 \\
\hline 7 & $\begin{array}{l}\text { Perdagangan, reparasi } \\
\text { motor dan mobil }\end{array}$ & 3,77 & 3,94 & 3,96 \\
\hline 8 & $\begin{array}{l}\text { Transportasi dan } \\
\text { pergudangan }\end{array}$ & 0,43 & 0,49 & 0,49 \\
\hline 9 & $\begin{array}{l}\text { Penyediaan akomodasi } \\
\text { dan makan minum }\end{array}$ & 0,20 & 0,22 & 0,23 \\
\hline 10 & $\begin{array}{ll}\text { Informasi } & \text { dan } \\
\text { komunikasi } & \end{array}$ & 0,35 & 0,38 & 0,37 \\
\hline 11 & $\begin{array}{l}\text { Jasa keuangan dan } \\
\text { asuransi }\end{array}$ & 0,66 & 0,61 & 0,59 \\
\hline 12 & Real estate & 0,67 & 0,76 & 0,75 \\
\hline 13 & Jasa perusahaan & 0,00 & 0,00 & 0,00 \\
\hline 14 & $\begin{array}{l}\text { Administrasi } \\
\text { pemerintahan, } \\
\text { pertahanan dan } \\
\text { jaminan sosial wajib }\end{array}$ & 2,52 & 2,63 & 2,50 \\
\hline 15 & Jasa pendidikan & 0,54 & 0,61 & 0,61 \\
\hline 16 & $\begin{array}{l}\text { Jasa kesehatan dan } \\
\text { kegiatan sosial }\end{array}$ & 0,16 & 0,19 & 0,18 \\
\hline 17 & Jasa lainnya & 0,40 & 0,47 & 0,47 \\
\hline & Jumlah & 100,00 & 100,00 & 100,00 \\
\hline
\end{tabular}

Sumber : BPS, Kuansing dalam Angka Tahun 2017
7,21 pada tahun 2014 menjadi 7,68 pada tahun 2016. Selanjutnya sektor lain terhadap pertumbuhan PDRB Kabupaten Kuantan Singingi, hanya berkisar 0,00 - 3,96 persen dengan titik terendah terjadi pada sektor jasa perusahaan dan tertinggi sektor perdagangan. 


\subsection{Identifikasi Pola Pertumbuhan Ekonomi Sektoral Kabupaten Kuantan Singingi}

\begin{tabular}{lrr}
\multicolumn{2}{c}{ dan kontribusi } & PDRB \\
masing-masing & sektor \\
kabupaten/kota yang & dibandingkan \\
dengan pertumbuhan & sektor di \\
provinsi diklasifikasi ke dalam
\end{tabular}

Pengamatan pertumbuhan ekonomi dengan pendekatan sektoral kabupaten/kota melalui penggabungan secara sistematis terhadap laju pertumbuhan PDRB kategori menurut Klassen Typologi. Setelah dianalisis, rata-rata pertumbuhan untuk tingkat provinsi pada periode 2014-2016 dapat dilihat pada Tabel 2.

Tabel 2. Laju Pertumbuhan PDRB dan Kontribusi PDRB Kabupaten Kuantan Singingi (persen)

\begin{tabular}{|c|c|c|c|c|}
\hline \multirow[t]{2}{*}{ Lapangan Usaha } & \multicolumn{2}{|c|}{$\begin{array}{l}\text { Laju Pertumbuhan } \\
\text { PDRB Rata-rata (\%) }\end{array}$} & \multicolumn{2}{|c|}{$\begin{array}{c}\text { Kontribusi PDRB } \\
\text { Rata-rata }(\%)\end{array}$} \\
\hline & Riau & $\begin{array}{l}\text { Kuantan } \\
\text { Singingi }\end{array}$ & Riau & $\begin{array}{l}\text { Kuantan } \\
\text { Singingi }\end{array}$ \\
\hline $\begin{array}{l}\text { Pertanian, kehutanan dan } \\
\text { perikanan }\end{array}$ & 3,52 & 3,36 & 38,22 & 48,94 \\
\hline Pertambangan dan penggalian & $-5,47$ & $-16,60$ & 1,08 & 6,74 \\
\hline Industri pengolahan & 4,62 & 5,99 & 31,35 & 26,70 \\
\hline Listrik dan gas & 10,87 & 20,90 & 0,37 & 0,03 \\
\hline $\begin{array}{l}\text { Pengadaan air, pengelolaan } \\
\text { sampah, limbah dan daur ulang }\end{array}$ & 1,01 & 0,90 & - & 0,02 \\
\hline Konstruksi & 6,59 & 3,96 & 4,44 & 7,52 \\
\hline $\begin{array}{l}\text { Perdagangan besar dan eceran, } \\
\text { reparasi mobil dan motor }\end{array}$ & 3,44 & 2,84 & 11,66 & 3,89 \\
\hline Transportasi dan pergudangan & 5,48 & 7,48 & 3,39 & 0,47 \\
\hline $\begin{array}{l}\text { Penyediaan akomodasi dan } \\
\text { makan minum }\end{array}$ & 4,01 & 7,69 & 6,20 & 0,22 \\
\hline Informasi dan komunikasi & 5,91 & 2,94 & - & 0,37 \\
\hline Jasa keuangan dan assuransi & 3,64 & 0,23 & 3,28 & 0,62 \\
\hline Real estate & 5,06 & 4,82 & - & 0,73 \\
\hline Jasa perusahaan & 7,72 & 5,69 & - & 0 \\
\hline $\begin{array}{l}\text { Administrasi pemerintahan, } \\
\text { pertahanan dan jaminan sosial }\end{array}$ & 1,87 & 2,19 & - & 2,55 \\
\hline Jasa pendidikan & 4,31 & 4,71 & - & 0,59 \\
\hline $\begin{array}{l}\text { Jasa kesehatan dan kegiatan } \\
\text { sosial }\end{array}$ & 6,30 & 6,46 & - & 0,18 \\
\hline Jasa lainnya & 9,21 & 7,38 & 6,20 & 0,45 \\
\hline $\begin{array}{l}\text { Berdasarkan } \\
\text { Typologi pola pertumbuhan se } \\
\text { ekonomi yang dapat dikategori } \\
\text { sebagai sektor maju dan tum }\end{array}$ & & $\begin{array}{l}\text { cepat ada } \\
\text { kehutanan } \\
\text { inilah yan } \\
\text { perhatian y } \\
\text { Daerah Kab }\end{array}$ & $\begin{array}{rr}\text { h } & \text { sek } \\
\text { an } & \text { per } \\
\text { sebaik }\end{array}$ & $\begin{array}{l}\text { pertan } \\
\text { nan. Sel } \\
\text { a menda } \\
\text { i Pemerin } \\
\text { itan Singi }\end{array}$ \\
\hline
\end{tabular}


untuk dikembangkan. Sektor pertanian, kehutanan dan perikanan mempunyai kinerja kontribusi ekonomi yang lebih besar daripada Provinsi Riau yaitu 48,94 persen terhadap PDRB Kabupaten Kuantan pertumbuhan 3,36 persen. Klasifikasi pola pertumbuhan sektor ekonomi Kabupaten Kuantan Singingi menurut Klassen Typologi dapat dilihat pada Tabel 3 .

Singingi dengan rata-rata laju

Tabel 3. Pola dan Struktur Pertumbuhan Ekonomi Daerah menurut Klassen Typology

\begin{tabular}{|c|c|c|}
\hline Kontribusi & $\mathrm{p}_{\mathrm{i}}>\mathrm{p}$ & $\mathrm{p}_{\mathrm{i}}<\mathrm{p}$ \\
\hline$r_{i}>r$ & $\begin{array}{l}\text { Daerah Maju dan } \\
\text { Tumbuh Cepat } \\
\text { - Tidak ada }\end{array}$ & $\begin{array}{l}\text { Daerah Maju tapi } \\
\text { tertekan } \\
\text { 1. Pertanian, } \\
\text { Kehutanan dan } \\
\text { perikanan. } \\
\text { 2. Pertambangan } \\
\text { dan penggalian } \\
\text { 3. Konstruksi }\end{array}$ \\
\hline$r_{i}<r$ & $\begin{aligned} & \text { Daerah } \text { Berkembang } \\
& \text { Cepat } \\
& \text { 1. } \text { Industri } \\
& \text { pengolahan } \\
& \text { 2. Listrik dan gas } \\
& \text { 3. Penyediaan } \\
& \text { akomodasi dan } \\
& \text { makan minum } \\
& \text { 4. Jasa }\end{aligned}$ & $\begin{array}{l}\text { Daerah Relatif } \\
\text { Tertinggal } \\
\text { 1. Pengadaan air } \\
\text { 2. Perdagangan } \\
\text { 3. Informasi dan } \\
\text { komunikasi } \\
\text { 4. Jasa keuangan }\end{array}$ \\
\hline
\end{tabular}

Berdasarkan hasil perbandingan laju pertumbuhan PDRB dan kontribusi PDRB di masing-masing sektor, pertanian termasuk kuadran II yaitu sektor maju tetapi tertekan. Sektor pertanian mempunyai kinerja kontribusi ekonomi yang lebih besar daripada Provinsi Riau yaitu 48,94 persen rata-rata kontribusi PDRB Kabupaten Kuantan Singingi dan 38,22 persen untuk kontribusi sektor pertanian terhadap PDRB Provinsi
Riau. Sektor pertanian mempunyai kinerja laju pertumbuhan PDRB yang lebih kecil dibandingkan laju pertumbuhan PDRB sektor pertanian di Provinsi Riau, yaitu sebesar 3,36 persen untuk Kabupaten Kuantan Singingi dan 3,52 persen untuk Provinsi Riau. Hal ini mengharuskan sektor pertanian berada pada kuadran II, yaitu sektor ini berkembang dengan pesat, tetapi tertekan karena dapat dikatakan sektor pertanian ini telah jenuh. 
Laju pertumbuhan sektor pertanian di Kabupaten Kuantan Singingi sedikit mengalami peningkatan dari 0,70 persen di tahun 2015 menjadi 4,41 persen di tahun 2016, namun dari rata-rata laju pertumbuhan PDRB sektor pertanian masih di bawah rata-rata laju pertumbuhan sektor pertanian di Provinsi Riau. Apabila dilihat dari kontribusi PDRB di Kabupaten Kuantan Singingi, peranan yang terbesar dalam penciptaan nilai tambah pada perekonomian Kabupaten Kuantan Singingi setiap tahunnya meskipun besarnya cenderung berfluktuasi. Pada tahun 2014 berperan sebesar 47,74 persen, tahun 2015 berperan 49,48 persen dan terakhir tahun 2016 berperan sebesar 49,61 persen.

Hal ini menunjukkan bahwa rata-rata kontribusi sektor pertanian di Kabupaten Kuantan Singingi lebih besar daripada kontribusi sektor pertanian di Provinsi Riau. Karena laju pertumbuhan PDRB sektor pertanian di Kabupaten Kuantan Singingi yang lebih kecil dari pada di Provinsi Riau yang menjadikan sektor pertanian berada pada klasifikasi sektor yang maju tetapi tertekan. Oleh sebab itu, diperlukan kegiatan atau usaha yang mendukung dan mendorong peningkatan laju pertumbuhan ekonomi sektor pertanian di Kabupaten Kuantan Singingi yang semakin menurun, agar sektor ini tidak tertekan dan tentunya dapat bersaing dengan kabupaten/kota yang ada di Provinsi Riau. Dalam hal ini diperlukan kebijakan untuk mengembangkan sektor pertanian dengan berbagai cara untuk memodifikasi pertanian dengan sektor lain, misalnya dilakukannya agoindustri, agrowisata, agribisnis dan lain-lain. Jika laju pertumbuhan PDRB sektor pertanian di Kabupaten Kuantan Singingi dapat meningkat dan lebih besar daripada di Provinsi Riau, sektor ini dapat di jadikan sebagai sektor yang maju dan berkembang cepat dan tentunya dapat dijadikan sektor unggulan yang harus diprioritaskan di Kabupaten Kuantan Singingi.

Dilihat dari hasil analisis Klassen Typologi tidak ada satu sektor pun yang berada pada kuadran I yaitu sektor maju dan tumbuh pesat. Berdasarkan analisis ini belum ada sektor yang sedang booming. Hal ini karena tidak ada sektor yang mampu menunjukkan laju pertumbuhannya yang melebihi kontribusi dan laju pertumbuhan di Provinsi Riau. Namun, jika dilihat dari rata-rata laju pertumbuhan PDRB sektor yang hampir mendekati nilai laju pertumbuhan PDRB sektor di Provinsi Riau yaitu sektor Industri Pengolahan. Dengan adanya perkembangan terus menerus maka sektor ini bisa berada pada kuadran I yang menjadi sektor yang maju dan berkembang cepat.

Berdasarkan analisis Klassen Typologi ternyata masih banyak sektor ekonomi yang berada dalam kuadran IV yaitu sektor yang relatif tertinggal. Klassen Typologi menjelaskan bahwa sektor-sektor ini kurang berkembang, karena dilihat dari hasil analisis laju pertumbuhan dan kontribusi sektor-sektor ini di Kabupaten Kuantan Singingi lebih kecil daripada di Provinsi Riau. Kebijakan pembangunan yang terpusat pada sektor ini memiliki efek multiplier rendah dan sektor 
swasta yang kurang berkembang menjadi penyebab sektor-sektor tersebut tidak berkembang. Sektorsektor yang termasuk kategori ini yaitu sektor pengadaan air, perdagangan, informasi dan komunikasi dan jasa keuangan. Hal ini dapat dilihat dari kinerja laju pertumbuhan dan kontribusi sektorsektor tersebut di Kabupaten Kuantan Singingi lebih kecil daripada kinerja di Provinsi Riau.

\subsection{Analisis Location Quotient}

Alat analisis Location Quotient (LQ) ini digunakan untuk mengidentifikasi

keunggulan komparatif kegiatan ekonomi (biasa disebut juga sebagai sektor basis)

Tabel 4. Hasil Perhitungan LQ Kabupaten Kuantan Singingi

\begin{tabular}{|c|l|r|r|c|}
\hline \multirow{2}{*}{ No } & \multirow{2}{*}{ Kecamatan } & \multicolumn{3}{|c|}{ LQ } \\
\cline { 3 - 5 } & & Karet & Kakao & Kelapa Sawit \\
\hline 1 & Kuantan Mudik & 0,57 & 0,12 & 1,13 \\
\hline 2 & Hulu Kuantan & 1,16 & 0,00 & 0,65 \\
\hline 3 & Gunung Toar & 1,76 & 0,00 & 0,06 \\
\hline 4 & Pucuk Rantau & 0,60 & 0,00 & 1,22 \\
\hline 5 & Singingi & 1,66 & 0,00 & 0,15 \\
\hline 6 & Singingi Hilir & 0,58 & 0,00 & 1,23 \\
\hline 7 & Kuantan Tengah & 1,15 & 0,00 & 0,66 \\
\hline 8 & Sentajo Raya & 0,87 & 0,00 & 0,95 \\
\hline 9 & Benai & 0,71 & 0,01 & 1,10 \\
\hline 10 & Kuantan Hilir & 0,92 & 0,00 & 0,89 \\
\hline 11 & Pangean & 1,20 & 0,00 & 0,62 \\
\hline 12 & Logas Tanah Darat & 0,93 & 0,00 & 0,89 \\
\hline 13 & Kuantan Hilir Seberang & 1,77 & 0,00 & 0,04 \\
\hline 14 & Cerenti & 1,10 & 0,03 & 0,69 \\
\hline 15 & Inuman & 1,36 & 0,00 & 0,46 \\
\hline
\end{tabular}

Tingginya nilai LQ pada subsektor tanaman karet di Kecamatan Kuantan Hilir Seberang $(1,77)$ dan Kecamatan Gunung Toar $(1,76)$ serta Kecamatan Singingi $(1,66)$ disebabkan oleh kontribusi di kecamatan-kecamatan yang ada di Kabupaten Kuantan Singingi dengan membandingkannya. Berdasarkan analisis LQ sebagaimana terlihat pada Tabel 4, yang khusus dilihat dari sektor pertanian tanaman perkebunan maka di Kabupaten Kuantan Singingi terdapat dua komoditi tanaman perkebunan yang berkontribusi besar terhadap penciptaan PDRB yang memiliki keunggulan komparatif, yaitu: komoditi karet dan kelapa sawit. Jika dilihat per kecamatan, maka keunggulan komparatif pada sektor pertanian di Kabupaten Kuantan Singingi sangat dipengaruhi oleh subsektor tanaman perkebunan, hal ini terlihat dari nilai LQ pada Tabel 4. subsektor ini dalam perekonomian kecamatan tersebut yang sangat dominan. Hal tersebut karena salah satu komoditi tanaman karet menjadi andalan di kecamatan-kecamatan tersebut. Berdasarkan data dari Dinas Tanaman Perkebunan diperoleh data 
luas tanam karet pada tahun 2016 di Kabupaten Kuantan Singingi seluas 144.314,70 ha (Lampiran 6).

Selain komoditi tanaman karet, tanaman kelapa sawit juga cukup potensial di Kabupaten Kuantan Singingi karena memiliki nilai LQ lebih dari satu (LQ > 1, khususnya di Kecamatan Kuantan Mudik, Pucuk Rantau, Singingi Hilir dan Benai. Dengan demikian keunggulan komparatif sektor pertanian di Kabupaten Kuantan Singingi disumbang oleh 2 sektor, yaitu tanaman karet dan kelapa sawit.

Secara umum tampak bahwa perekonomian Kabupaten Kuantan Singingi masih bercirikan ekonomi tradisional dimana sektor pertanian menjadi andalan perekonomian daerah. Di sisi lain, belanja pemerintah tampaknya juga masih menjadi faktor dominan dalam menggerakkan perekonomian daerah. Sinyal ini memberikan petunjuk pentingnya penelitian ini guna mengidentifikasi sektor/subsektor ekonomi potensial di Kabupaten Kuantan Singingi.

Suatu sektor ekonomi memiliki keunggulan kompetitif sekaligus spesialisasi jika pertumbuhan dan peranannya lebih baik dibandingkan dengan pertumbuhan dan peranan sektor yang sama dalam perekonomian di Provinsi Kuantan Singingi. Adapun subsektor ekonomi yang memiliki keunggulan kompetitif sekaligus spesialisasi di Kabupaten Kuantan Singingi hanya satu yaitu subsektor tanaman perkebunan. Keunggulan kompetitif sekaligus spesialisasi pada subsektor tanaman perkebunan ini tampak anomali, dimana sektor pertaniannya justru tidak memiliki kedua keunggulan secara bersamaan. Sektor pertanian di Kuantan Singingi memiliki spesialisasi, tetapi tidak punya daya saing.

Hal ini dapat dijelaskan bahwa meskipun subsektor tanaman perkebunan memiliki keunggulan kompetitif dan spesialisasi, namun keunggulannya masih kurang kuat untuk mendongkrak ketidakunggulan subsektor lainnya. Sehingga sektor pertanian masih belum memiliki daya saing secara sektoral.

$$
\text { Untuk itu kebijakan }
$$

pembangunan wilayah dalam meningkatkan perekonomian di Kabupaten Kuantan Singingi diprioritaskan pada dua sektor tersebut, karena kedua sektor ini sangat berperan penting dalam menghasilkan pendapatan. Selain itu, kedua sektor tersebut sebagai sektor basis juga diharapkan mampu meningkatkan pertumbuhan pendapatan wilayah Kabupaten Kuantan Singingi. Beberapa implikasi kebijakan dari setiap sektor adalah sebagai berikut: 1. Implikasi kebijakan dari sektor pertanian diharapkan dapat membantu masyarakat petani dengan adanya penyebaran perusahaan pertanian dan Penyuluh Praktek Lapang untuk dapat membantu masyarakat petani khususnya dalam pengelolaan lahan pertanian di setiap kecamatan. Peran swasta dalam mengelola hasil pertanian khususnya di bidang perkebunan agar dapat memberi bantuan kepada masyarakat dengan penyerapan tenaga kerja dan pendapatan masyarakat. 2. Sektor pertanian dapat menghasilkan nilai tambah dan partisipasi masyarakat yang terus meningkat dan berkembang dengan dilakukanya 
usaha pertanian yang berwawasan bisnis, dengan dikembangkannya agribisnis dan agrowisata di Kabupaten Kuantan Singingi. Selain itu juga agroindustri sebagai subsistem agribisnis yang mempunyai potensi sebagai pendorong pasar yang lebih luas dan nilai tambah (value added) yang besar. Mengembangkan sistem ketahanan pangan dan gizi melalui peningkatan ketersediaan komoditas pangan dalam jumlah yang memenuhi kebutuhan masyarakat dan kualitas yang baik. Selain itu, dengan mengembangkan perekonomian yang berorientasi global yang mampu bersaing dengan daerah lain dengan memprioritaskan produk-produk ungulan pertanian baik dari tanaman pangan, perkebunan, perikanan, peternakan, serta kehutanan. Kebijakan lain yang bisa dilakukan misalnya dengan lebih meningkatkan teknologi intensifikasi pertanian dan diversifikasi pertanian.

\section{KESIMPULAN DAN SARAN}

\subsection{Kesimpulan}

1. Hasil dari analisis Klassen Typologi dengan pendekatan sektoral, menunjukkan bahwa sektor pertanian tanaman perkebunan khusunya karet dan kelapa sawit menduduki kuadran II yaitu sektor maju tapi tertekan. Selain itu, sektor ekonomi di Kabupaten Kuantan Singingi belum ada yang berada di kuadran I yaitu maju dan tumbuh cepat tapi masih banyak berada pada kuadran IV yaitu sektor yang relatif tertinggal.
2. Hasil perhitungan nilai LQ diseluruh sektor pertanian khususnya tanaman perkebunan perekonomian yaitu tanaman karet di Kecamatan Kuantan Hilir Seberang (1,77) dan Kecamatan Gunung Toar (1,76) serta Kecamatan Singingi $(1,66)$ serta tanaman kelapa sawit juga cukup potensial di Kabupaten Kuantan Singingi karena memiliki nilai LQ lebih dari satu (LQ > 1, khususnya di Kecamatan Kuantan Mudik, Pucuk Rantau, Singingi Hilir dan Benai. Hal ini menunjukkan bahwa sektorsektor tersebut memiliki kontribusi yang besar dalam perekonomian dan pembangunan wilayah di Kabupaten Kuantan Singingi.

\subsection{Saran}

1. Pemerintah Kabupaten Kuantan Singingi perlu melakukan perencanaan pembangunan daerah dengan bahan masukan dan implikasi kebijakan sebagai berikut: Menjadikan subsektor tanaman perkebunan sebagai subsektor ekonomi potensial di Kabupaten Kuantan Singingi sebagai prioritas pembangunan ekonomi yang perlu ditumbuhkembangkan dalam mencapai pertumbuhan ekonomi yang tinggi dan pemerataan pendapatan masyarakat. Dengan tetap mengacu pada rencana strategis yang ada, Pemerintah Kabupaten 
Kuatan Singingi harus tetap memacu dan mengembangkan kegiatan ekonomi lain secara lintas sektoral dan terintegrasi untuk mengejar ketertinggalan pembangunan dibanding daerah lainnya. Langkah dimaksud adalah melalui penciptaan "forward linkage dan backward linkage" atau saling keterkaitan antar berbagai kegiatan ekonomi, yang dapat menimbulkan multiplier effect yang positif. Pembangunan infrastruktur jalan, jembatan, pasar, penyediaan sarana transportasi, informasi pasar serta jaminan keamanan berusaha bagi masyarakat merupakan simpul bagi kepastian keberhasilan pembangunan ekonomi masyarakat.

2. Sektor unggulan yang akan diprioritaskan untuk peningkatan pendapatan masyarakat dan pembangunan wilayah harus didukung oleh ketersediaan sarana dan prasarana yang cukup untuk mendukung aktivitas perekonomian dan yang mendukung perkembangan sektor unggulan tersebut. Beberapa sarana dan prasarana yang mendukung perkembangan sektor unggulan di Kabupaten Kuantan Singingi, yaitu; pasar, koperasi, kelompok tani, penyuluh praktek lapang (PPL), perusahaan pertanian. Sebaiknya pembangunan

\begin{abstract}
sarana dan prasarana ditingkatkan di wilayah kecamatan yang terletak jauh dari ibukota kecamatan yang relatif masih tertinggal serta daerah yang banyak memiliki potensi dari sektor unggulan.
\end{abstract}

\section{DAFTAR PUSTAKA}

Alfonso W., 1999.

Ketidakseimbangan Kota dan

Daerah, Ekonomi Keuangan Indonesia Vol. XXVII. No.3.Jakarta, September.

Arsyad, L. 1999. Pengantar Perencanaan dan Pembangunan Ekonomi Daerah. Yogyakarta : BPFE.

Aziz, J.I. 1994. Ilmu Ekonomi Regional dan Beberapa Aplikasinya di Indonesia. Lembaga Penerbit Fakultas Ekonomi Universitas Indonesia, Jakarta.

Bachrul Elmi, 2004. Studi Pembiayaan Pembangunan Perkotaan (urban development finance) Kota Prabumulih, Kajian Ekonomi dan Keuangan., Vol.8, No.1. Maret.

Bendavid-Val., Avrom, 1991. Regional and Local Economic Analysis for Practitioners, Fourth edition, New York: Prager Publisher.

Bintarto.R., 1996. Interaksi DesaKota dan Permasalahannya. Ghalia Indonesia. Jakarta.

Boediono, 1985. Teori Pertumbuhan Ekonomi., Yogyakarta, BPFE-UGM.

Glasson John, 1990. Pengenalan Perancangan Wilayah Konsep dan Amalan (alih bahasa 
Ahris Yaakup). Dewan bahasa dan Pustaka Kementrian Pendidikan Malaysia Kualalumpur.

Handoko, Budiono, 1994. Interaksi antara Desa dan Kota, PPE FE UGM dan deptan RI Yogyakarta.

Hoover., E.M., 1977. An Introduction to Regional Economics. (1 st ed.). New York: Alfred A.Knopf, Inc.

Indahsari, K. 2001. Penentuan Prioritas Pembangunan Berdasarkan Tingkat Perkembangan Kecamatan dan Potensi Wilayah. Tesis Magister Sains. Program Pascasarjana, Institut Pertanian Bogor, Bogor.

Kadariah, 1987. Perhitungan Pendapatan Nasional. Jakarta : LP3ES.

Lincolin Arsyad, 1997, Ekonomi Pembangunan, Sekolah Tinggi Ilmu Ekonomi YKPN, Yogyakarta 1999. Pengantar

Perencanaan Dan Pembangunan Ekonomi Daerah, Edisi Pertama, BPFE - UGM, Yogyakarta.

Mudrajat Kuncoro. 2000. Ekonomi Pembangunan: Teori, Masalah dan Kebijakan UPP AMP YKPN. Yogyakarta. 2002, Ekonomi Pembangunan, Teori, Masalah, dan Kebijakan, Akademi Peremajaan Perusahaan, YKPN, Yogyakarta , 2003. Analisis Spasial dan Regional: Studi Aglomerasi dan Klaster Industri
Indonesia. UPP AMP YKPN. Yogyakarta.

Prasetyo Soepono, 2001. Teori Pertumbuhan Berbasis Ekonomi (eksport) Posisi dan Sumbangannya bagi Perbendaharaan Alat-alat Analisis Regional. Jurnal Ekonomi dan Bisnis Indonesia. Vol.16 No.1.

Rahardjo Adisasmita, 2005. DasarDasar Ekonomi Wilayah. Graha Ilmu. Yogyakarta.

Richardson Harry.,W. 1977. DasarDasar Ilmu Ekonomi Regional. (terjemahan: Paul Sitohang). LPFE-UI. Jakarta.

Robinson Tarigan, 2005, Ekonomi Regional, PT Bumi Aksara, Jakarta

Sadono Sukimo, 2002, Pengantar Teori Makro ekonomi, PT RajaGrafindo Persada, Jakarta

Soeparmoko, 2002. Ekonomi Publik Untuk Keuangan dan Pembangunan Daerah. Edisi pertama. Andi. Yogyakarta.

Sukanto R dan Karseno, 1997. Ekonomi Perkotaan. BPFE UGM Yogyakarta.

Syafrizal, 1993. Ekonomi Regional : Suatu Perkembangan dalam Ilmu Ekonomi. Ekonomi Keuangan Indonesia. Vol.XXXI.No.2, Jakarta, Juni Tarigan, R. 2005. Ekonomi Regional, Teori dan Aplikasi. PT.Bumi Aksara, Jakarta.

Todaro., M.P. 1997. Economic Development. Six Edition. Edinbourg Gate Harlow Addition Wesley Longman. New York University. 